\title{
The new portfolio of global precipitation data products of the Global Precipitation Climatology Centre suitable to assess and quantify the global water cycle and resources
}

\author{
Udo Schneider, Markus Ziese, Anja Meyer-Christoffer, Peter Finger, Elke Rustemeier, and \\ Andreas Becker \\ Global Precipitation Climatology Centre, Deutscher Wetterdienst, 63067 Offenbach am Main, Germany \\ Correspondence to: Andreas Becker (andreas.becker@dwd.de)
}

Published: 17 October 2016

\begin{abstract}
Precipitation plays an important role in the global energy and water cycle. Accurate knowledge of precipitation amounts reaching the land surface is of special importance for fresh water assessment and management related to land use, agriculture and hydrology, incl. risk reduction of flood and drought. High interest in long-term precipitation analyses arises from the needs to assess climate change and its impacts on all spatial scales. In this framework, the Global Precipitation Climatology Centre (GPCC) has been established in 1989 on request of the World Meteorological Organization (WMO). It is operated by Deutscher Wetterdienst (DWD, National Meteorological Service of Germany) as a German contribution to the World Climate Research Programme (WCRP). This paper provides information on the most recent update of GPCC's gridded data product portfolio including example use cases.
\end{abstract}

\section{GPCC background and agenda}

The GPCC collects and assures quality of world-wide observational in-situ data from rain gauges in order to provide gridded high-quality and high-resolution land surface precipitation analyses as mandated by WMO's World Climate Research Program and the Global Climate Observing System (GCOS). Based on over 25 years of operation the GPCC gridded data products are built on base of the world-wide largest archive of quality controlled in-situ precipitation data (Fig. 1). All gridded GPCC data products are public available in OGC compliant netCDF format to the community (ftp: //ftp-anon.dwd.de/pub/data/gpcc/html/download_gate.html).

\subsection{A product portfolio for archetype requirements}

Depending on the climate related application and service aspired, there is a large variety of user needs in terms of timeliness, homogeneity, resolution and accuracy which cannot be addressed by one data product. As a consequence GPCC has issued a suite of products that contains near-real-time as well as non-real-time products in monthly and daily resolution and in spatial resolutions of $1.0^{\circ} \times 1.0^{\circ}$ and $2.5^{\circ} \times 2.5^{\circ}$ (only monthly) latitude by longitude. The non-real-time products based on the complete GPCC monthly rainfall station database (the largest monthly precipitation station database of the world with data from more than 100000 different stations) are also available in $0.5^{\circ} \times 0.5^{\circ}$ resolution. GPCC's new global precipitation climatology V.2015 (available in $2.5^{\circ} \times 2.5^{\circ}, 1.0^{\circ} \times 1.0^{\circ}, 0.5^{\circ} \times 0.5^{\circ}$, and $0.25^{\circ} \times 0.25^{\circ}$ resolution, Fig. 2) based on data from the more than 75000 stations that feature records longer than 10 years of length is used as background climatology for the other GPCC analyses using the anomaly interpolation method also known as climate aided interpolation (CAI).

\subsection{Data sources of GPCC}

Data from national meteorological and hydrological services, regional and global data collections are mainly used to calculate these products, as well as WMO-GTS data. In order to provide the user with a sufficient level of documentation and long term accessibility, GPCC products issued in year 2011 or later are all referenced by digital object identi- 


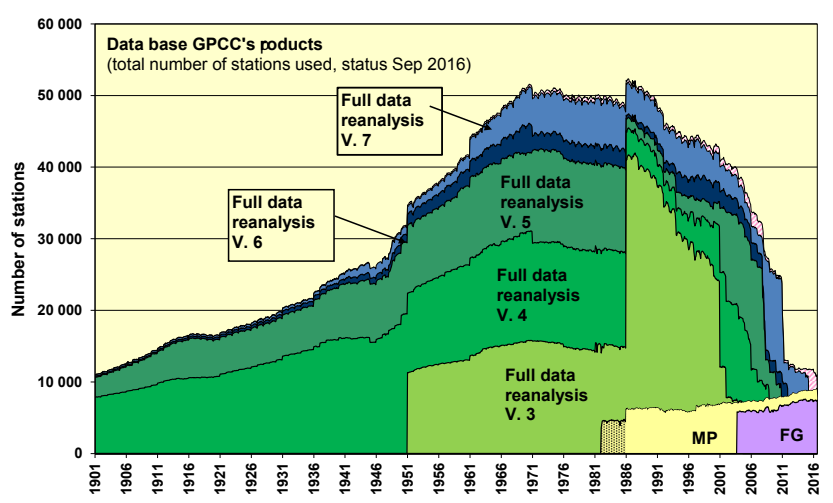

Figure 1. Station data coverage of GPCC's near real-time "Monitoring Product" and "First Guess Product" (indicated by "FG"), as well as for the five most recent Versions of the centennial "Full Data Reanalysis with the most recent Version 7" from June 2015.

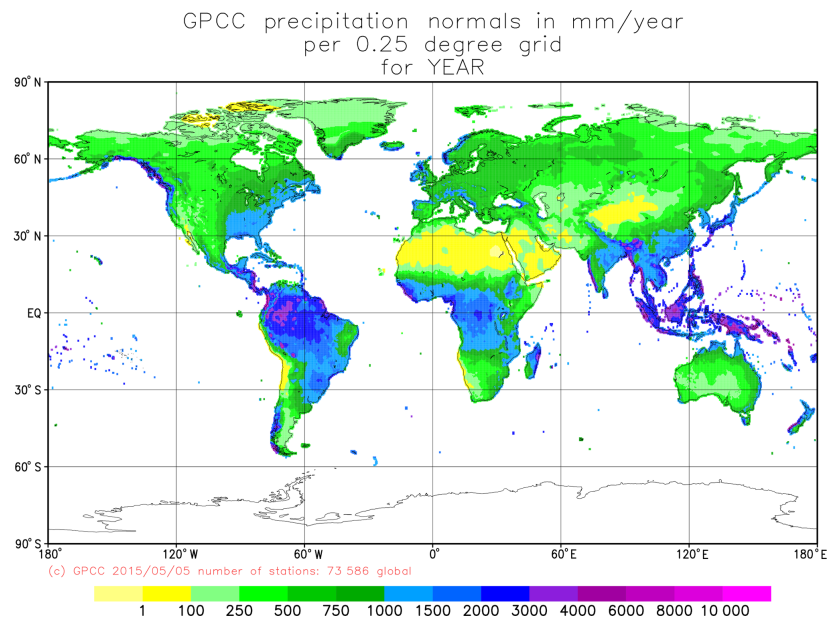

Figure 2. GPCC Climatology V2015, annual totals in $\mathrm{mm}$ are shown at $0.25^{\circ}$ resolution.

fiers (DOIs, Tables 1 and 2), allowing also for reproducibility and repetition of data utilizations even decades after primary data accesses. Corresponding to international agreements, station data provided by Third Parties are protected. However the gridded GPCC analysis products are freely available via Internet (http://gpcc.dwd.de) and GPCC has also issued a test interpolation data set solely based on the public available station data of NOAAs GHCN.

\section{Most recent versions of monthly data products issued in June 2015}

Most recently updated versions of the Full Data Reanalysis (V7) and Climatology (V2015) were released, replacing their predecessors issued in 2011. The updates are enhanced by almost 8000 additional stations that were added to the quality assured data base of the GPCC. Furthermore the data records of existing stations were extended by the most re-

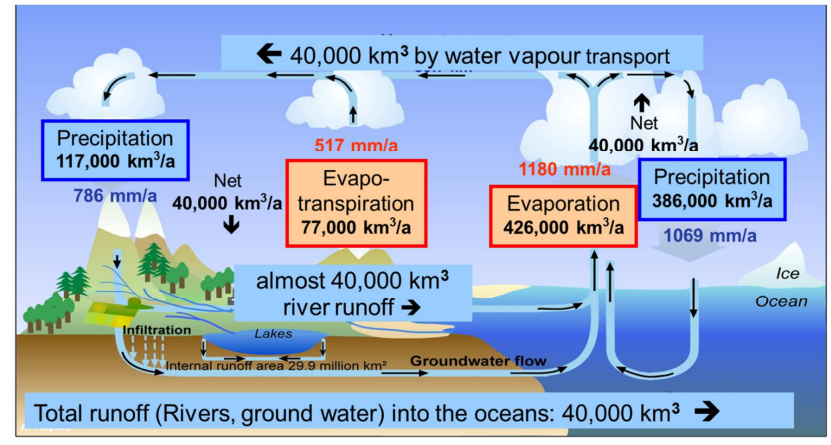

Figure 3. Update of the quantitative assessment of the global water cycle utilizing GPCCs land-surface precipitation analysis (Schneider et al., 2014).

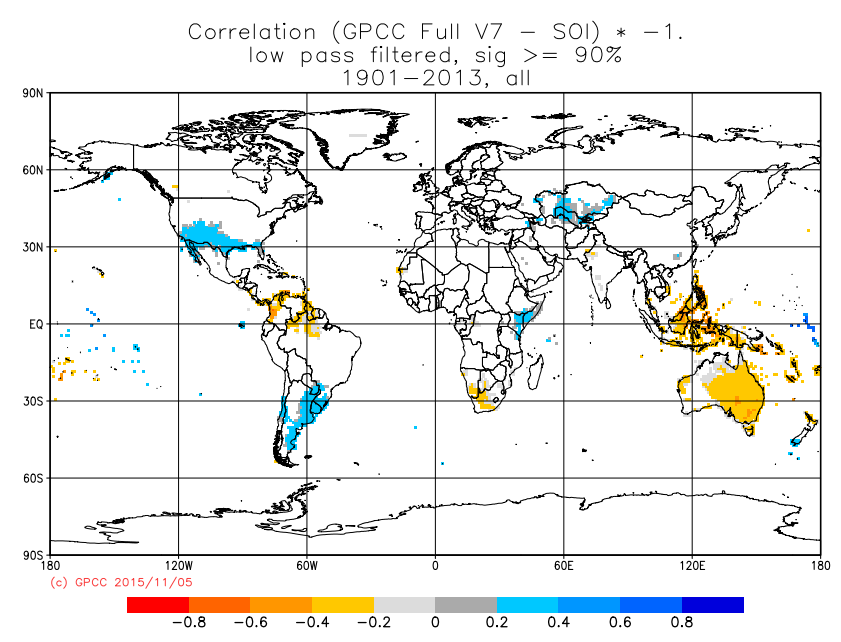

Figure 4. Centennial correlation between precipitation (GPCC Full Data Reanalysis V7) for the period 1901-2013 and the negative ENSO Southern Oscillation index $(-1 \times \mathrm{SOI})$ similar to Becker et al. (2013).

cent years. All in all, the new versions are based on about 75100 stations with records exceeding 10 years instead of 67200 stations reprocessed in year 2011. Due to the additional stations and precipitation data, it was possible to detect errors invisible so far and to improve the analysis in particular across Indonesia, Mexico, Brazil and some other regions. Moreover a new land-sea mask has been introduced, adding many grid cells across islands/atolls that had been missing (sea cells) before. The GPCC Full Data Reanalysis Product is the most recommended for quantitative assessments of the global water cycle (Fig. 3) and resources with regard to the precipitation over land (Schneider et al., 2014). It also contains information to understand natural variabilities (Fig. 4) as well as the hydro-climatological background of water related conflicts (Fig. 5). Since July 2015 a first full data daily product (Fig. 6) has been published together with three other new ones (Table 2). 
Table 1. Overview on monthly data products of the GPCC and their use cases.

\begin{tabular}{|c|c|c|c|c|c|}
\hline \multicolumn{3}{|c|}{ Name of GPCC data product } & \multicolumn{3}{|c|}{ DOI reference for download } \\
\hline Use cases & $\begin{array}{l}\text { Period } \\
\text { covered }\end{array}$ & $\begin{array}{l}\text { Time of } \\
\text { availability }\end{array}$ & $\begin{array}{l}\text { Regular } \\
\text { updates }\end{array}$ & $\begin{array}{l}\text { - Quality } \\
\text { - (\# of stations) } \\
\text { - QC-level }\end{array}$ & $\begin{array}{l}\text { Grid } \\
\text { resolution }\end{array}$ \\
\hline \multicolumn{3}{|c|}{ First guess monthly } & \multicolumn{3}{|c|}{ doi:10.5676/DWD_GPCC/FG_M_100 } \\
\hline $\begin{array}{l}\text { - Near real-time drought } \\
\text { monitoring } \\
\text { - Early monitoring }\end{array}$ & $\begin{array}{l}\text { Oct. } 2003 \\
\text { until present }\end{array}$ & $\begin{array}{l}3-5 \text { days after } \\
\text { expiry of } \\
\text { month } \\
\text { regarded }\end{array}$ & Yes, monthly & $\begin{array}{l}\text { - Limited } \\
-(6000 \text { to } \\
7600) \\
\text { - Basic (Auto) }\end{array}$ & $\begin{array}{l}\text { Lat-Lon } \\
1.0^{\circ}\end{array}$ \\
\hline \multicolumn{3}{|c|}{ Monthly product V5 (June 2015) } & \multicolumn{3}{|c|}{$\begin{array}{l}\text { doi:10.5676/DWD_GPCC/MP_M_V5_100 } \\
\text { doi:10.5676/DWD_GPCC/MP_M_V5_100 }\end{array}$} \\
\hline $\begin{array}{l}\text { - Regular HQ } \\
\text { monitoring } \\
\text { - Calibration of satellite } \\
\text { data } \\
\text { - Sys. error (under } \\
\text { catch) correction } \\
\text { - Solid precipitation } \\
\text { - Annual and monthly } \\
\text { anomalies }\end{array}$ & $\begin{array}{l}\text { Jan. } 1982 \\
\text { until present }\end{array}$ & $\begin{array}{l}\text { Within two } \\
\text { months after } \\
\text { end of month } \\
\text { regarded }\end{array}$ & Yes, monthly & $\begin{array}{l}\text { - High } \\
-(7000 \text { to } \\
8900) \\
\text { - Normal } \\
\text { (auto and } \\
\text { cross-checks) }\end{array}$ & $\begin{array}{l}\text { Lat-Lon } \\
1.0 \text { and } 2.5^{\circ}\end{array}$ \\
\hline
\end{tabular}

\begin{tabular}{lll} 
& \multicolumn{2}{c}{ Full data reanalysis V7 (June 2015) } \\
\hline - Global water cycle & Jan 1901 to & Upon \\
and resources & Dec 2013 & availability of \\
- Hydrological studies & & substantially \\
- Best quality (HR) & increased data \\
analysis & base of quality \\
- Centennial analysis & controlled \\
- Climatological & precipitation \\
analysis & data \\
- Index (ENSO) & \\
sensitive regions & \\
- Verification of models & \\
from NWP to seasonal & \\
- Re-analysis & \\
verification & \\
\hline
\end{tabular}

doi:10.5676/DWD_GPCC/FD_M_V7_050 doi:10.5676/DWD_GPCC/FD_M_V7_100 doi:10.5676/DWD_GPCC/FD_M_V7_250

\begin{tabular}{lll}
\hline No, & - Best & Lat-Lon \\
every three to & $-(11000$ to & $0.5,1.0$, and \\
four years & 51000 & $2.5^{\circ}$ \\
& depending on & \\
& month; 75 100 & \\
& in total $)$ & \\
& - High (in- & \\
depth & \\
screening and & \\
correction) & \\
& \\
&
\end{tabular}

doi:10.5676/DWD_GPCC/CLIM_M_V2015_025 doi:10.5676/DWD_GPCC/CLIM_M_V2015_050 doi:10.5676/DWD_GPCC/CLIM_M_V2015_100 GPCC climatology V2015 (June 2015)

\begin{tabular}{lll}
\hline - Climate aided & Reference & Similar to full \\
interpolation (CAI) & period & data \\
- School material & $1951-2000$ & reanalysis \\
- Reference material & & \\
\hline
\end{tabular}
doi:10.5676/DWD_GPCC/CLIM_M_V2015_250

\begin{tabular}{lll}
\hline No, & - Best & Lat-Lon \\
similar to & -751000 & $0.25,0.5,1.0$, \\
full data & - High & and $2.5^{\circ}$ \\
reanalysis & &
\end{tabular}




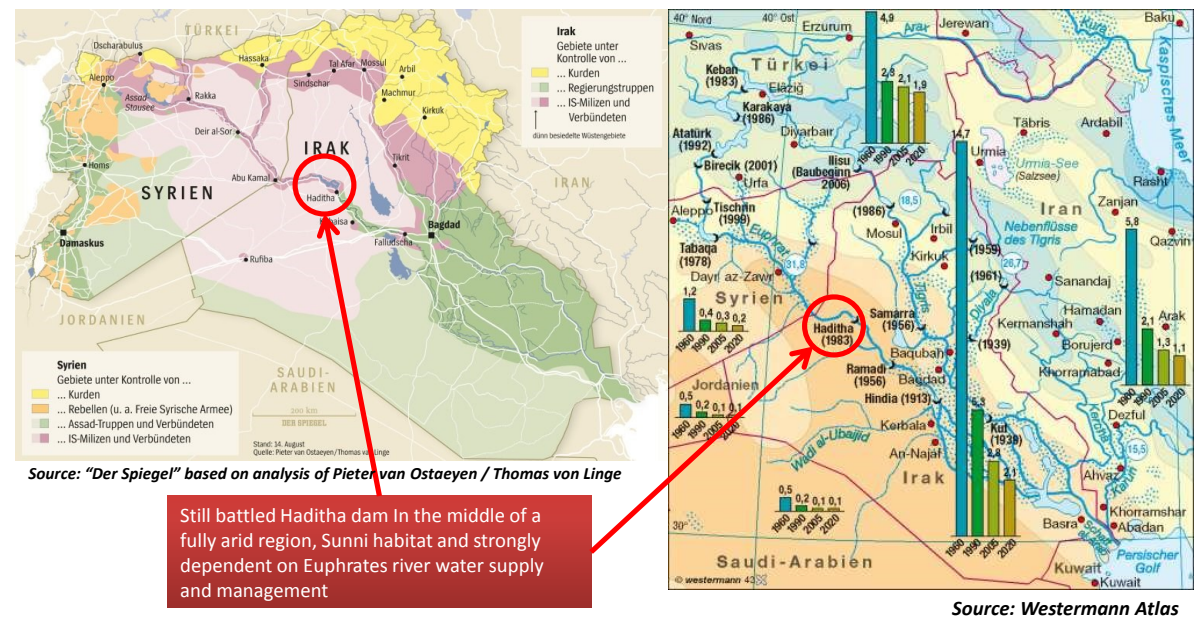

Figure 5. GPCC's climatological data sets are utilized as reference material (right panel, here Westermann Atlas) and potentially help to comprehensively understand water modulated conflicts (left panel) and to serve independent reference information for water diplomacy.
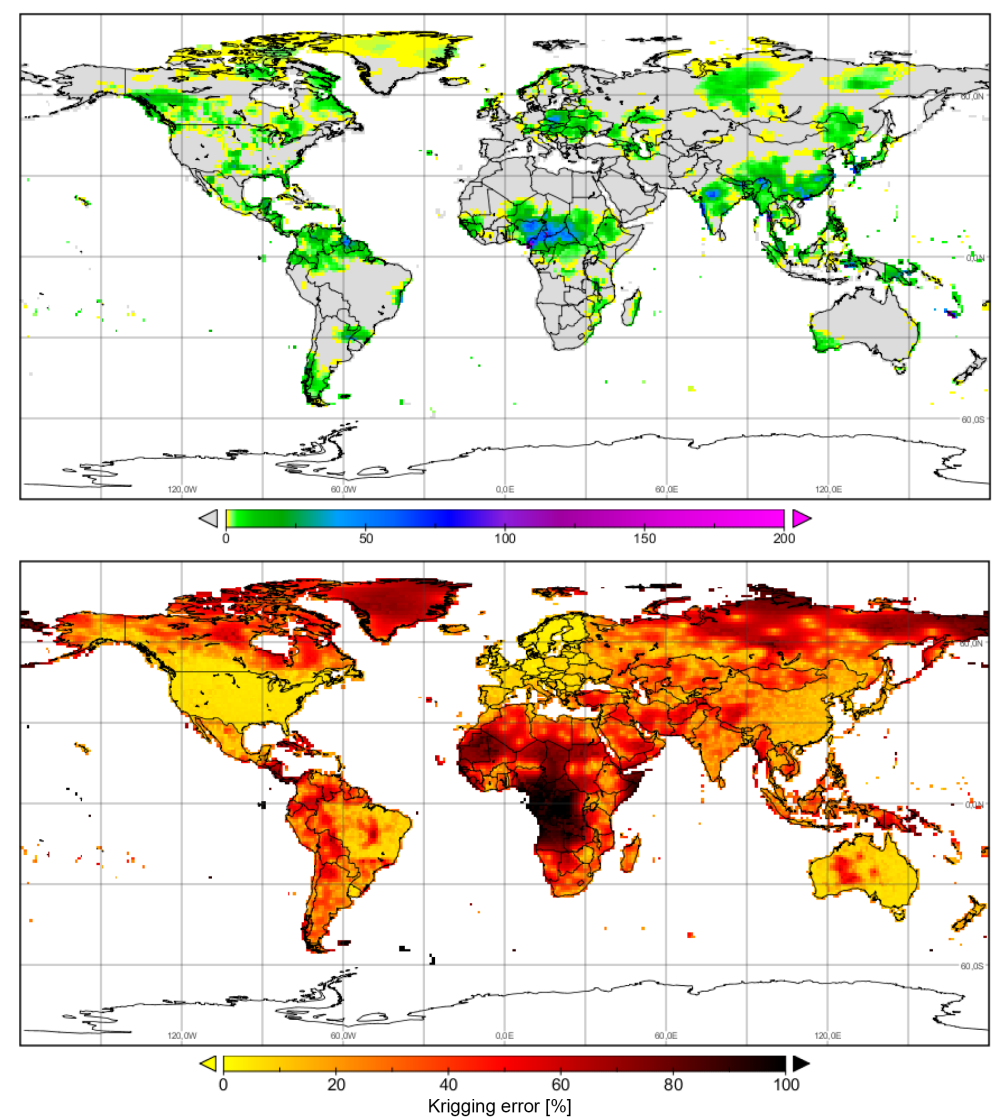

Figure 6. Precipitation analysis of 7 July 1997 (top panel) and corresponding interpolation (kriging) error field (bottom panel). 
Table 2. New GPCC data products issued in July 2015.

\begin{tabular}{|c|c|c|c|c|c|}
\hline \multicolumn{3}{|c|}{ Name of GPCC data product } & \multicolumn{3}{|c|}{ DOI reference for download } \\
\hline Use cases & $\begin{array}{l}\text { Period } \\
\text { covered }\end{array}$ & $\begin{array}{l}\text { Time of } \\
\text { availability }\end{array}$ & $\begin{array}{l}\text { Regular } \\
\text { updates }\end{array}$ & $\begin{array}{l}\text { - Quality } \\
\text { - (\# of stations) } \\
\text { - QC-level }\end{array}$ & $\begin{array}{l}\text { Grid } \\
\text { resolution }\end{array}$ \\
\hline \multicolumn{3}{|c|}{ GPCC interpolation test dataset } & \multicolumn{3}{|c|}{$\begin{array}{l}\text { doi:10.5676/DWD_GPCC/ITD_M_V1_100 } \\
\text { (including monthly station totals of GHCN) }\end{array}$} \\
\hline $\begin{array}{l}\text { - Verify GPCC's } \\
\text { interpolation method } \\
\text { through product based } \\
\text { on subset of } \sim 23000 \\
\text { public available } \\
\text { NOAA-GHCN } \\
\text { stations }\end{array}$ & $\begin{array}{l}\text { Jan-Dec } \\
1988\end{array}$ & $\begin{array}{l}\text { Similar to full } \\
\text { data } \\
\text { reanalysis }\end{array}$ & None & $\begin{array}{l}\text { - Test } \\
\text { - Up to } \\
24000 \\
\text { stations } \\
\text { - GHCN QC }\end{array}$ & $\begin{array}{l}\text { Lat-Lon } \\
1.0^{\circ}\end{array}$ \\
\hline \multicolumn{3}{|c|}{ GPCC drought index (monthly; Ziese et al., 2014) } & \multicolumn{3}{|c|}{ doi:10.5676/DWD_GPCC/DI_M_100 } \\
\hline - Drought monitoring & $\begin{array}{l}\text { Jan 2013- } \\
\text { present } \\
\text { expired } \\
\text { month }\end{array}$ & $\begin{array}{l}\text { 10th of } \\
\text { following } \\
\text { month }\end{array}$ & Yes, monthly & $\begin{array}{l}\text { - Limited } \\
-6000-7600 \\
\text { - Basic } \\
\text { (Auto) }\end{array}$ & $\begin{array}{l}\text { Lat-Lon } \\
1.0^{\circ}\end{array}$ \\
\hline \multicolumn{3}{|c|}{ GPCC first guess daily prod. (Schamm et al., 2014) } & \multicolumn{3}{|c|}{ doi:10.5676/DWD_GPCC/FG_D_100 } \\
\hline $\begin{array}{l}\text { - Early monitoring } \\
\text { - Extreme precipitation }\end{array}$ & $\begin{array}{l}\text { Jan 2009- } \\
\text { present } \\
\text { expired } \\
\text { month }\end{array}$ & $\begin{array}{l}\text { 4th of } \\
\text { following } \\
\text { month }\end{array}$ & & $\begin{array}{l}\text { - Limited } \\
\text { - 6000-7600 } \\
\text { - Basic } \\
\text { (Auto) }\end{array}$ & $\begin{array}{l}\text { Lat-Lon } \\
1.0^{\circ}\end{array}$ \\
\hline \multicolumn{3}{|c|}{ GPCC full data daily product version 1 (July 2015) } & \multicolumn{3}{|c|}{ doi:10.5676/DWD_GPCC/FD_D_V1_100 } \\
\hline $\begin{array}{l}\text { - Climatological } \\
\text { assessment } \\
\text { - Climate and weather } \\
\text { extremes in precip } \\
\text { (WCRP GC and } \\
\text { ETCCDI) } \\
\text { - Error assessment }\end{array}$ & $\begin{array}{l}\text { Jan } 1988- \\
\text { Dec } 2013\end{array}$ & $\begin{array}{l}\text { Upon } \\
\text { availability of } \\
\text { full data } \\
\text { monthly } \\
\text { product }\end{array}$ & $\begin{array}{l}\text { No, } 1 \text { month } \\
\text { after issuance } \\
\text { of full data } \\
\text { monthly } \\
\text { product }\end{array}$ & $\begin{array}{l}\text { - High } \\
-(23000- \\
30000) \\
\text { - Auto and } \\
\text { vis. check }\end{array}$ & $\begin{array}{l}\text { Lat-Lon } \\
1.0^{\circ}\end{array}$ \\
\hline
\end{tabular}

\section{Data availability}

All data sets are provided with free and unlimited access through the DOI references provided. Data will be maintained version dependent on the underlying ftp server operated by Deutscher Wetterdienst.

Acknowledgements. We are most appreciative to the data suppliers who are to the largest extent the worldwide spread National Meteorological and/or Hydrological Services, but also some other institutes. These data contributions have put Global Precipitation Climatology Centre (GPCC) into the position to provide the global precipitation analyses described in this document, and we are looking forward to their further contributions, which are crucial in order to maintain and enhance GPCC's level of products in terms of scope and quality.

\section{References}

Becker, A., Finger, P., Meyer-Christoffer, A., Rudolf, B., Schamm, K., Schneider, U., and Ziese, M.: A description of the global land-surface precipitation data products of the Global Precipitation Climatology Centre with sample applications including centennial (trend) analysis from 1901-present, Earth Syst. Sci. Data, 5, 71-99, doi:10.5194/essd-5-71-2013, 2013.

Diercke Weltatlas: Euphrat and Tigris - Water Usage, p. 162, Fig. 2, ISBN 978-3-14-100800-5, 2015.

Schamm, K., Ziese, M., Becker, A., Finger, P., Meyer-Christoffer, A., Schneider, U., Schröder, M., and Stender, P.: Global gridded precipitation over land: A description of the new GPCC First Guess Daily product, Earth Syst. Sci. Data, 6, 49-60, doi:10.5194/essd-6-49-2014, 2014. 
Schneider, U., Becker, A., Finger, P., Meyer-Christoffer, A., Ziese, M., and Rudolf, B.: GPCC's new land surface precipitation climatology based on quality-controlled in situ data and its role in quantifying the global water cycle, Theor. Appl. Climatol., 115, 15-40, 2014.
Ziese, M., Schneider, U., Meyer-Christoffer, A., Schamm, K., Vido, J., Finger, P., Bissolli, P., Pietzsch, S., and Becker, A.: The GPCC Drought Index - a new, combined, and gridded global drought index, Earth Syst. Sci. Data, 6, 285-295, doi:10.5194/essd-6-2852014, 2014. 